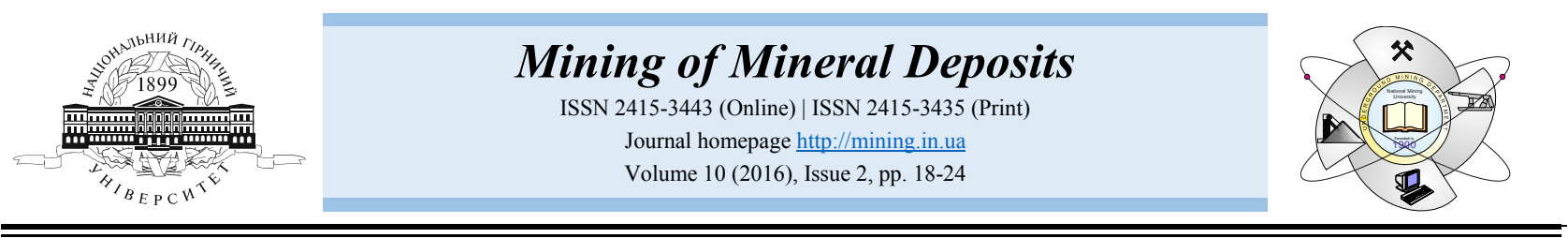

UDC 622.016

http://dx.doi.org/10.15407/mining10.02.013

\title{
MATHEMATICAL MODELING OF HYDRAULIC MINING FROM PLACER DEPOSITS OF MINERALS
}

\author{
Z. Malanchuk ${ }^{1}$, Ye. Malanchuk ${ }^{2 *}$, A. Khrystiuk ${ }^{2}$ \\ ${ }^{1}$ Department of Development of Deposits and Mining, National University of Water Management and Nature Resources Use, Rivne, Ukraine \\ ${ }^{2}$ Department of Automation, Electrical Engineering and Computer-integrated Technologies, National University of Water Manage- \\ ment and Nature Resources Use, Rivne, Ukraine \\ *Corresponding author: e-mail malanchykEZ@mail.ru, tel.+38096440255
}

\section{МАТЕМАТИЧНЕ МОДЕЛЮВАННЯ ПРОЦЕСУ ГІДРОВИДОБУТКУ КОРИСНИХ КОПАЛИН 3 РОЗСИПНИХ РОДОВИЩ}

\author{
3. Маланчук ${ }^{1}, €$. Маланчук ${ }^{2 *}$, А. Христюк ${ }^{2}$ \\ ${ }^{1}$ Кафедра розробки родовищ та видобування корисних копалин, Національний університет водного господарства та приро- \\ докористування, Рівне, Україна \\ ${ }^{2}$ Кафедра автоматизації, електротехнічних та комп'ютерно-інтегрованих технологій, Національний університет водного \\ господарства та природокористування, Рівне, Украӥна \\ *Відповідальний автор: e-mail malanchykEZ@mail.ru, тел. +380964402556
}

\begin{abstract}
Purpose. To analyze the process of hydraulic borehole mining of minerals. To define the main problems of hydraulic borehole mining. To create a mathematical model that will describe the process of hydraulic borehole mining of minerals.

Methods. The process of hydraulic borehole mining of minerals as the object of automation was analyzed. The mathematical dependences describing the stages of minerals jetting process and lifting them to the surface are obtained.

Findings. The main problems of hydraulic borehole mining and its basic processes are defined. The mathematical algorithm for the simulation of hydraulic borehole mining was identified. The basic indicators of jetting jetting were defined. The mathematical dependences describing the process of hydraulic borehole mining of minerals are obtained.

Originality. Scientific novelty consists in analyzing the process of hydraulic borehole mining, defining the main problems of hydraulic borehole mining and developing a mathematical model describing its process.

Practical implications. Creation of the mathematical model that allows to calculate and select equipment for implementation of hydraulic borehole mining.
\end{abstract}

Keywords: hydraulic borehole mining, modeling, hydraulic giant, stope, hydraulic fluid

\section{INTRODUCTION}

At the present stage of development of hydraulic borehole mining (HBM) technology the necessity of selecting qualitative bore samples comes on top while testing friable fields. The main problems are ineffectiveness of rock delivery to the surface by technological channels of hydraulic tool and changes of slurry composition directly in the mining chamber on testing fields, which affects the samples' composition. This happens due to incomplete or selective rock jetting, ineffective flushing of the rock mass, the processes of rocks sorting in mining chamber, different rate of various types of particles moving in the slurry pipelines.

The purpose of the present article is to analyze hydraulic borehole mining as the object of modeling and to develop a mathematical model of HBM of alluvial minerals.

\section{THE BASIC ANALYSIS AND MODELING}

Hydraulic borehole mining was most widely used in exploration works to perform the following tasks:

- large-scale testing of fields;

- research and methodological works on hydraulic borehole mining.

The main feature of many researches into using hydraulic borehole in mining industry is originality in the formulation and solution of problems of the jetting, hydraulic lifting, control of rock pressure, the process of slurry thickening and concentration. However, the slurry preparation technology was not considered in numerous studies of hydraulic borehole mining, although the development of effective technologies of slurry composition allows to significantly improve technical and economic parameters of hydraulic borehole mining of allu- 
vial fields. At the same time, because of considerable differences in conditions, objectives and tasks of works, calculation methods from other fields (mining, processing and chemical industries, hydraulic pipeline and hydrogeology) are unsuitable for description of the processes occurring in mining chambers.

The investigation of hydrodynamic processes in mining chambers will develop a more advanced methodology of HBM for producing large-sized samples by improving their quality, which will allow to replace expensive technologies by HBM.

To achieve this goal it is necessary to solve the following principal tasks of borehole hydraulic mining:

- to study basic technological schemes and patterns of solid particles transfer during hydrotransportation;

- to develop an engineering method of calculating hydraulic parameters in the stope, ensuring a rational level of losses and depletion of ore materials and increase in the efficiency of mining alluvial fields by HBM.

Analysis of hydraulic mining schemes shows that HBM tool is a complex hydraulic system that performs the following operations:

- injection of operating agents into the tool;

- transportation of operating agents in pipelines;

- rock destruction and its washing out into the state of slurry;

- transportation of slurry to the suction port of the tool;

- slurry suction;

- slurry lifting to the surface;

- filtration of the received mixture.

It is also advisable to organize a closed cycle of providing the process with fluid (a model of slurry settling, filtering the resulting liquid and returning it to the water intake reservoir for the hydraulic monitor) (Fig. 1).

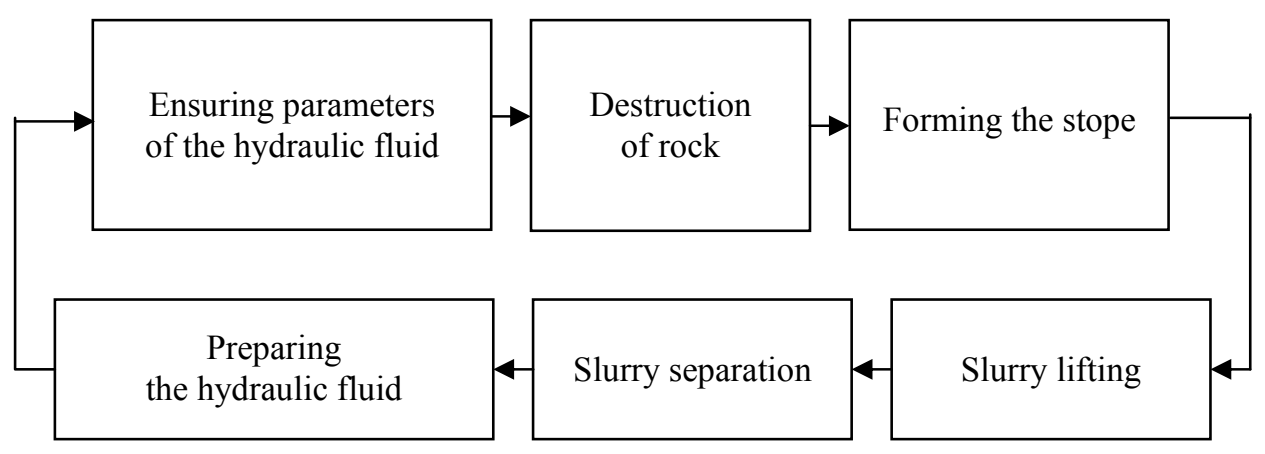

Figure 1. The structure of BHM mathematical model

At present time, due to wide use of computer systems in industry and science, it is reasonable to work out more universal design approaches for BHM, methods of solving BHM problems and to develop software for this purpose (Li, 2014).

Large-scale sampling in fields exploration is intended for taking samples of minerals to explore their technological properties. It is feasible to implement BHM technology for the wholesale fields testing, which is necessary to determine reserves in the fields with nonuniform distribution of minerals (alluvial deposits of precious metals and stones). As the researches have shown (Arens, 2001; Haldar, 2013), most large-scale testing is done on loose alluvial deposits, sometimes other types of sedimentary deposits.

Research and methodological studies of BHM are conducted when further exploitation of deposits is connected with the use of borehole hydraulic mining that is applied in complex mining and technical conditions, when the deposit development is impossible for economic reasons.

In the case of BHM sampling, the problem of roof fall can be solved by reducing the stope size and production time. A more serious problem is associated with the separation of mineral samples and precipitation of heavy (usually ore) components of the slurry at the bottom of the cleaning chamber.

Borehole hydraulic mining is a technically complex and expensive process, regardless of its purposes (exploration, research and industrial works, commercial mining of minerals).
Industrial experience in BHM implementation has shown that the technology is complicated by many factors that influence the performance of the extraction tools (Arens, 2001). High effectiveness of BHM can only be achieved by strict coordination of all technological processes. In this regard mathematical modeling of the system involving design and operation of hydraulic tool becomes relevant. Mathematical modeling at the design stage allows to estimate the cost-effectiveness, choose rational parameters of BHM and compare different technological schemes of production in order to select the optimal one.

Mathematical modeling of borehole hydraulic mining and further analysis of the obtained models will help to identify the most appropriate technical means and conditions of equipment operation to ensure the best possible technical and economic performance and quality of selected samples.

To start, it is necessary to formulate goals and objectives that will determine the accuracy and the necessary research methods for performing mathematical modeling of hydraulic mining. The next step is to develop technological schemes that will allow to visualize BHM process. The detailed schematic diagram of hydraulic mining tool (HMT) allows to visualize the modeled system, define its parameters and their interrelation. According to the proposed scheme, each HMT can be analysed according to 3 groups of data:

- static factors $\left(c_{i}\right)$ (mining and technical information, constants, strict technical specifications of the equipment); 
- adjustable (regime, $x_{i}$ ) parameters;

- output parameters (performance, energy consumption, volume of one borehole production etc, $y_{i}$ ).

In the mathematical model (the mathematical function of HMT, $f$ ), the first data group will be presented by constants, the second group - by function arguments, the third - by variables from the function range. Thus, in general form the mathematical model of the HMT can be presented as:

$y_{1} \ldots y_{k}=f\left(x_{1} \ldots x_{m}\right)$.

Parameter values and function arguments are defined in detailed consideration of the hydraulic mining tool.

The next stage in the development of mathematical model is drafting a system of equations and its solution. The mathematical model includes all identified functional dependencies between processes.

It should be noted that the mathematical description of the processes in the hydraulic mining tool is one of the most difficult and ambiguous problems of mathematical modeling.

Modern computer systems, software, CAD software allow to considerably simplify the process of modeling. Solving a complex system of equations is easier to conduct by numerical methods. It will reduce the probability of errors and simplify the process of solution.

Before proceeding to finding the solution it is necessary to define allowable variation interval of function arguments and the confidence interval for the solution of the system (in order to exclude areas of obviously faulty data).

It is obvious that the development of mathematical models of BHM for each case is different, and the process depends on the goals and tasks of modeling; initial data, factors and the accuracy of the simulation. Thus, it is impossible to offer specific methods of mathematical modeling, but we can determine the general sequence of actions in the form of mathematical modeling algorithm:

- analysis of geological conditions of the deposit, work experience, and technical units of hydraulic mining;

- identification of objectives and tasks of mathematical modeling;

- development of a technological scheme of the hydraulic mining tool;

- mathematical description of all processes of borehole hydraulic mining;

- developing a system of mathematical equations;

- getting solution to the system of equations and analysis of the results;

- choosing the optimal technology.

In the process of developing a system of equations and finding its solution it is advisable:

- to use interpolation methods to replace the mathematical functions with the simple ones (for more general points in the confidence area) and to provide functional description of discrete reference data;

- to present graphically data and functions, to perform visual analysis;

- to use numerical methods for solving equations, finding extremes, maximum and minimum values;
- to use discrete representation of the data to reduce the volume of calculations;

- to limit and simplify the goals of mathematical modeling;

- to consider static ( in time) modes of HMT operation to avoid bringing integral and differential dependencies into the system;

- to use available software for dealing with mathematical problems.

To test alluvial deposits by BHM through lone boreholes and groups of conventionally unrelated boreholes it is necessary to solve specific tasks, such as:

- to choose the optimal borehole diameter (in terms of technological capabilities of equipment);

- to determine the conditions of various technical means application for lifting slurry to the surface and the conditions of their rational exploitation;

- to choose technical means of destruction and slurry preparation;

- to conduct a comprehensive analysis of the selected geotechnological equipment.

The last task is the most difficult and important, because the complex methodology of calculation and modeling of BHM process has not been proposed yet.

Research of hydraulic mining tools and determination of their efficiency is closely related to the criteria which evaluate BHM effectiveness. We propose to use the following criteria of BHM effectiveness (Rehbinder, 1977):

- energy efficiency (or specific energy consumption);

- maximum production rate of borehole;

- productivity of mining;

- efficiency of mining;

- specific consumption of working agents;

- quality of the extracted material;

- cost of extracting rock mass;

- capital intensity of the technology.

In studying BHM applied to shallow alluvial deposits, we should operate not only with analytical dependencies and technological process but also with specific data. Analyzing the experience of BHM, conditions of deposits occurrence in loose rocks, we can derive the following averaged conditions (Malanchuk, 2002):

- depth of formation $50-100 \mathrm{~m}$;

- power of seams $1-10 \mathrm{~m}$;

- grain size 0 - $20 \mathrm{~mm}$ not less than $95 \%$;

- particle hydraulic size to $1 \mathrm{~m} / \mathrm{sec}$;

- coefficient of productive area filtration $0-10 \mathrm{~m} /$ day;

- static water level of productive seam to the surface;

- energy consumption of soil washing-out not more than $2-5 \mathrm{~kW} / \mathrm{t}$.

Comprehensive analysis of BHM technology and technical means allows us to set the following limits of modeling (group of technical factors):

- one borehole system of extraction by independent boreholes;

- borehole diameter within 100 - $400 \mathrm{~mm}$;

- technical device for slurry lifting: airlift;

- working pressure of the liquid 5-10 $\mathrm{MPa}$; air pressure $0.6-0.8 \mathrm{MPa}$;

- the maximum allowable density of slurry in the lifting column $1100 \mathrm{~kg} / \mathrm{m}^{3}$. 
For further modeling we will single out the principal flow schematic of hydraulic mining tools with soil delivery to the surface via airlift, which is most relevant to the state-of the-art BHM technology and equipment applied for the development of shallow loose deposits and unconsolidated ores (Haimson \& Cornet, 2003).

Some BHM issues are currently considered in scientific literature, but in general the whole process of BHM has not been summarized yet. In order to comprehensively study BHM as a single mechanism, we need to combine mathematical models of the processes to synthesize a complex mathematical model. Let us consider some mathematical descriptions of BHM processes.

The process of hydraulic jetting. The main indicators of hydraulic jetting (by immersed jets) are: jetting performance $\Pi, \mathrm{m}^{3} / \mathrm{h}$; range of jetting $R, \mathrm{~m}$; power of jet from hydraulic giant $W, \mathrm{~m}^{3} / \mathrm{sec}$; a dynamic pressure of jet $P_{d}$, MPa or dynamic thrust of jet $H_{d}, \mathrm{~m}$; fluid flow through hydraulic giant $Q, \mathrm{~m}^{3} / \mathrm{sec}$; nozzle diameter $d_{0}, \mathrm{~m}$ and differential pressure on the nozzle $H_{H}, \mathrm{~m}$.

The most important task in the calculation of soil jetting is to determine the working radius of jetting and jetting performance. To find these parameters we must perform a series of calculations using the formulas below. We will determine the rate along the axis of the immersed water jet by the Konovalov formula generally accepted for the description of immersed jets' work of medium pressure hydraulic giant (Turton, 1991):

$$
\frac{v_{c}}{v_{0}}=\frac{0.145}{0.145+\frac{\alpha R}{d_{0}}},
$$

where:

$v_{0}$ - jet rate at the outlet of the nozzle, $\mathrm{m} / \mathrm{sec}$;

$v_{c}$-average jet rate along the axis, $\mathrm{m} / \mathrm{sec}$ at a distance $l, \mathrm{~m}$;

$\alpha$-coefficient of turbulent structure, for curved cylindrical nozzles $0.066-0.050$.

According to Abramovich solution we determine the maximum jet rate along the axis using the ratio:

$v=2.5 \ldots 3 v_{c}$.

Dynamic pressure of jet can be expressed via its rate:

$$
H_{D}=\frac{v}{2 g} \text {. }
$$

We will express the value $v_{0}$ in (2) by differential pressure on the nozzle:

$$
H_{H}=\frac{v_{0}^{2}}{g} \Rightarrow v_{0}=\sqrt{2 g H_{H}} .
$$

Taking into account the coefficient of resistance of hydraulic giant nozzles, $\mu=0.93-0.95$, the formula takes the form:

$$
v_{0}=\sqrt{2 \mu g H_{H}} \text {. }
$$

The diameter of hydraulic giant is related to the consumption of liquid by the following equation:

$Q_{H}=\frac{\pi d_{0}^{2}}{4} \Rightarrow d_{0}=\sqrt{\frac{4 Q_{H}}{\pi v_{0}}}$.

In order to evaluate the destructive capacity of the hydraulic giant at some distance $R$, it is necessary to determine the dynamic pressure in the jet axis. We can obtain the values of dynamic pressure from the expressions $(2)-(7)$ :

$$
H_{H}=\left(2.75 \sqrt{2 \mu g H_{H}} \frac{0.145}{0.145+\alpha R \sqrt{\frac{\pi \sqrt{2 \mu g H_{H}}}{4 Q_{H}}}}\right)^{2} \frac{1}{2 g} .
$$

Expression (8) allows to relate external factors of BHM hydraulic system to the dynamic pressure of the jet at a distance $R$, which makes it possible to evaluate the potential of equipment for jetting rock mass. It is necessary to define only the rock thickness in the area of jetting and correlate it with the dynamic pressure applied along the axis. The critical (jetting) pressure for the rock is defined by the formula (Babichev, 1985):

$$
P_{K P}=\left(C_{B P}-C_{D L}\right)+\rho_{H} \cdot g \cdot H \cdot \operatorname{tg} \varphi \cdot\left(1-K_{K} K_{B}\right),
$$

where:

$$
\begin{aligned}
& \rho_{H}-\text { density of rocks that form the mass, } \mathrm{kg} / \mathrm{m}^{3} ; \\
& H-\text { depth of the seam under jetting, } \mathrm{m} ; \\
& \varphi-\text { internal friction angle of the rock under jetting; } \\
& K_{K} \text { - coefficient of strain concentration in the mass; } \\
& K_{B} \text { - coefficient of lateral pressure. } \\
& \text { Soil jetting is possible if: }
\end{aligned}
$$$$
H_{H} \geq 10^{2} P_{K P} \text {. }
$$

We can get the maximum radius of soil jetting from expressions (8), (9) and (10):

$$
R=\left(\frac{0.04 \sqrt{\mu H_{H}}}{\sqrt{P_{K}}}-0.145\right) \frac{1}{\alpha} \sqrt{\frac{4 Q_{H}}{\pi \sqrt{2 \mu g H_{H}}}} .
$$

We will use expression (11) while modeling hydraulic jetting of rock mass for determining the size of the stope.

The productivity of hydraulic giant jetting is defined by the hydraulic power spent on the process $W, \mathrm{~kW}$ :

$W=10 H_{H} Q_{H}$.

Then the productivity $\Pi \mathrm{t} / \mathrm{h}$ can be expressed by the formula:

$$
\Pi=\frac{W}{A}=\frac{10 H_{H} Q_{H}}{A},
$$

where:

$A$-energy intensity of water jetting, maximum $5 \mathrm{~kW} \cdot \mathrm{h} / \mathrm{t}$, taking into account works in a flooded mine. 
Since for the purpose of further calculations it is more convenient to use the productivity value expressed in $\mathrm{m} / \mathrm{s}$, we will transform the expression (13):

$$
\Pi=\frac{0.28 H_{H} Q_{H}}{A \rho_{H}} .
$$

This formula is based on the assumption that the working energy of the jet slightly decreases at a distance of $1-2 \mathrm{~m}$, so big radii of jetting are not considered in the modeling.

Studies showed that most mining objects were developed by jets of medium pressure $(3-10 \mathrm{MPa})$ with the flow rate of $50-300 \mathrm{~m}^{3} / \mathrm{h}$, with stopes radii $0.5-3 \mathrm{~m}$ (Babichev, 1985). For the purpose of modeling, we will limit the range of pressure and flow of fluid values between these limits.

Dimensions of stope. In the case of relatively stable roof and walls of the borehole, the stope formed by BHM has a certain configuration. Otherwise the slurry flows under the force of gravity until the access to minerals is blocked by the roof. The stope has a difficult geometry and is formed in several stages. If we assume the form of the stope to be equal to subspherical idealized shape, its volume can be expressed as:

$V=2 \pi \int_{0}^{\frac{h}{2}}\left(\sqrt{R^{2}-z^{2}}+R\right)^{2} d z$.

It is more rational to equate the volume of this figure to the volume of the ellipsoid of equal size:

$V=\frac{\pi}{6} h(h+2 R)^{2}$.

Density of the slurry. During excavation by the hydraulic jet with the capacity $\Pi$ and subsequent absorption of the produced slurry, with absorption capacity $Q_{2}$, density of the resulting slurry can be calculated as follows:

$\rho_{2}=\frac{\Pi\left(\rho_{V}-\rho_{B}\right)}{Q_{2}}+\rho_{B}$.

Operation of the jet pump. We use the formula below to describe the jet pump work (with the central working nozzle):

$\beta=0.14 \alpha^{0.64}$.

This formula was obtained by mathematical processing of practical data received by N.G. Malukhin (Malanchuk, 2002) to describe the pump eductor working on slurry suction for the modes of its maximum efficiency. In formula (18):

$\beta=\frac{H_{3}-H_{2}}{H_{1}-H_{2}}$,

where:

$H_{1}$ - pressure in the eductor nozzle, $\mathrm{m}$;

$H_{2}$ - pressure of the pumped media m;

$\mathrm{H}_{3}$ - pressure of eductor pumping, $\mathrm{m}$.
$\alpha=\frac{Q_{1} \rho_{1}}{Q_{2} \rho_{2}}$,

where:

$Q_{1}$ - feeding of hydraulic fluid, $\mathrm{m}^{3} / \mathrm{s}$;

$Q_{2}$ - productivity of the slurry suction, $\mathrm{m}^{3} / \mathrm{s}$;

$\rho_{1}-$ density of the hydraulic fluid, $\mathrm{kg} / \mathrm{m}$;

$\rho_{2}-$ density of the slurry, $\mathrm{kg} / \mathrm{m}$.

It is convenient to combine expressions (14), (15) and (16) to solve the problems of modeling.

$\frac{H_{3}-H_{2}}{H_{1}-H_{2}}=0.14\left(\frac{Q_{2} \rho_{2}}{Q_{1} \rho_{1}}\right)^{0.64}$.

While calculating a hydraulic lift, the diameter of the mixing chamber will be the benchmark sufficient for all slurry factions in terms of granulometric distribution.

We can use the following equation for the mixing chamber:

$Q_{3}=v_{m x} \frac{\pi d_{m x}^{2}}{4}=\sqrt{2 \mu g H_{3}} \sqrt{\frac{\rho_{v}}{\rho_{3}}} \cdot \frac{\pi d_{m x}^{2}}{4}$.

Whence the diameter of the mixer can be expressed:

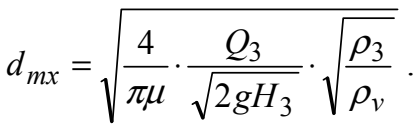

The density of the slurry at the outlet of the hydraulic lift is defined by the formula:

$\rho_{3}=\frac{Q_{2}\left(\rho_{2}-\rho_{v}\right)}{Q_{3}}+\rho_{v}$.

Pressure loss of hydraulic fluid. We use DarcyWeisbach equation to calculate the specific pressure loss in the discharge line:

$i_{p}=\frac{\lambda}{d} \cdot \frac{v_{p}^{2}}{2 g}$,

where:

$v_{p}$ - flow rate of water column;

$\lambda$ - coefficient of resistances which is calculated by Altshul formula, considering the liquid movement in columns to be turbulent:

$\lambda=0.11\left(\frac{\Delta_{e}}{d}+\frac{68}{\mathrm{Re}}\right)$,

where:

$\Delta_{e}$ - roughness of the columns, which is taken approximately equal to $0.2 \mathrm{~mm}$;

$d$ - diameter of pipes;

Re - Reynolds number, equal to:

$\operatorname{Re}=\frac{d v_{\Pi}}{\gamma}$ 
where:

$\gamma$-viscosity of water, approximately equal to $10^{-6} \mathrm{~m}^{2} / \mathrm{sec}\left(\right.$ at $20^{\circ} \mathrm{C}$ ). The rate of the fluid in the column is determined by the formula:

$v=\frac{4 Q}{\pi d^{2}}$.

Combining expressions (25) and (26) in one formula, we get:

$i=0.018\left(\frac{\Delta}{d}+\frac{17 \pi \gamma d}{Q}\right) \cdot \frac{Q^{2}}{d^{5}}$.

Calculating pressure loss in the discharge line is necessary to define the working pressure of the nozzle and eductor of hydraulic giant. Taking into account the hydrostatic pressure, we can determine the absolute pressure in units of the hydraulic giant:

$H_{1}=H_{0}+H-1.2 i_{p} l$,

where:

$l$ - length of the discharge line,

$H_{0}$ - injection pressure based on characteristics of pump equipment.

Pressure loss in the slurry lifting column. If the unstructured slurry moves in the vertical and steeply inclined pipelines, pressure loss can be determined the way it is done for the clean fluid, taking into account the following: the minimum movement rate through pipelines should be not lower than critical; the mode of mixture motion should always be turbulent.

The specific pressure loss is determined by the formula:

$i_{\Pi}=\frac{\lambda}{D-d} \cdot \frac{v^{2}}{2 g}$.

The coefficient of resistance $\lambda$ is defined by:

$\lambda=\frac{0.31}{(\lg \operatorname{Re}-1)^{2}}$.

Reynolds number is calculated by the formula:

$\operatorname{Re}=\frac{(D-d) v}{\gamma}$.

The rate of upward flow is determined by the formula:

$v=\frac{4 Q}{\pi\left(D^{2}-d^{2}\right)}$.

Combining formulas (31) to (34) we obtain:

$i=\frac{0.026}{\lg \left(\frac{4 Q}{D+d}-1\right)} \cdot \frac{Q^{2}}{(D-d)^{3}(D+d)^{2}}$.

We can determine the pressure required for pumping of the slurry on the basis of the pressure loss in the slurry lifting column and density of the rising slurry:

$H_{3}=\rho_{3} g H+1.2 i l$, where:

$l$ - the length of slurry lifting column, $\mathrm{m}$.

The dependences describing dynamics of phosphorite rock destruction (Malanchuk, 2002) show a rapid destruction of rock in the initial moment, at a short distance between the nozzle and the prop stay. With increasing the distance between them, the pressure on the wall of the pothole decreases. Destruction of rocks stops and the distance of jetting does not change when the pressure drops to a critical value.

So the process of jetting is a complex object, where parameters depend on the conditions of the process (pressure in the nozzle, physical and mechanical parameters of rocks, environment of jets motion, distance from the nozzle to the wall of the pothole, shape and size of the nozzle etc.) and are determined by experimental data.

Such choice of the controlled parameters does not allow to perform effective process control for several reasons:

- the slurry density measurements are carried out on the surface, which results in a big transport delay;

- washed-out rock is delivered to the surface by airlift or hydraulic elevators whose efficiency decreases as the slurry consistency changes;

- settling of the eroded rock while transporting it to the lifting gear also affects the change of the slurry consistency.

\section{CONCLUSIONS}

Considering the main operational parameters of the jet - differential pressure at the nozzle (dynamic pressure of the jet at the outlet of the nozzle) and fluid flow through the nozzle of the hydraulic giant, which are interrelated via diameter and initial velocity jet, we have considered their impact on the area of jetting. After analyzing the dependencies for the working range of pressures and outlet, we can conclude that increasing injection pressure and flow rate contributes to the range of jetting. The greater the distance, the lower the intensity of increasing jetting distance by changing the operating parameters. According to the considered dependence, increase in the flow rate has a greater impact on jetting radius, compared with the increase in pressure. Therefore, we can conclude that in the development of tasks for BHM use one should design radii of jetting in the vicinity of $1 \mathrm{~m}$. In this case the problem of extending the radius of jetting is better solved by increasing consumption of hydraulic fluid.

\section{ACKNOWLEDGMENTS}

The authors express their gratitude to the staff of the Institute of Geotechnical Mechanics named after M.S Polyakov of the National Academy of Sciences of Ukraine (Dnipropetrovsk, Ukraine) and personally to Professor Volodymyr Nadutyi.

\section{REFERENCES}

Arens, V. (2001). Fiziko-khimicheskaya geotekhnologiya. Moskva: Izdatel'stvo Moskovskogo gosudarstvennogo gornogo universiteta.

Babichev, N. (1985). The technology of hydraulic borehole mining of minerals. Mosow: MGRI. 
Haimson, B., \& Cornet, F. (2003). ISRM Suggested Methods for rock stress estimation - Part 3: hydraulic fracturing (HF) and/or hydraulic testing of pre-existing fractures (HTPF). International Journal of Rock Mechanics and Mining Sciences, 40(7-8), 1011-1020.

http://dx.doi.org/10.1016/j.ijrmms.2003.08.002

Haldar, S. (2013). Mineral Exploration - Case Histories. Mineral Exploration, 287-322.

http://dx.doi.org/10.1016/b978-0-12-416005-7.00015-5

$\mathrm{Li}, \mathrm{D}$. (2014). Underground hydraulic mining of thin sub-layer as protective coal seam in coal mines. International Journal of Rock Mechanics and Mining Sciences, (67), 145-154. http://dx.doi.org/10.1016/j.ijrmms.2014.01.014

Malanchuk, Z. (2002). Scientific basis for the borehole hydrotechnologies. Rivne: RSTU.

Rehbinder, G. (1977). Slot cutting in rock with a high rate water jet. International Journal of Rock Mechanics and Mining Sciences \& Geomechanics Abstracts, 14(5-6), 229-234. http://dx.doi.org/10.1016/0148-9062(77)90734-3

Turton, K. (1991). Pumps and Pumping. Plant Engineer's Reference Book, 18/1-18/32.

http://dx.doi.org/10.1016/b978-0-7506-1015-5.50024-7

\section{ABSTRACT (IN UKRAINIAN)}

Мета. Провести аналіз процесу свердловинного гідровидобутку. Визначити основні показники гідромоніторного розмиву. Створити математичну модель, яка описуватиме процес свердловинного гідровидобутку корисних копалин.

Методика. Проведено аналіз процесу свердловинного гідровидобутку як об'єкта моделювання. Отримано математичні залежності, що описують етапи процесу розмиву корисної копалини та піднімання іï на поверхню.

Результати. Визначено основні завдання свердловинного гідровидобутку та основні процеси, що його характеризують. Виявлено алгоритм математичного моделювання процесу свердловинного гідровидобутку. Визначено основні показники гідромоніторного розмиву. Отримано математичні залежності, що описують процес свердловинного гідровидобутку корисних копалин.

Наукова новизна. Наукова новизна полягає у проведенні аналізу процесу свердловинного гідровидобутку, визначенні основних показників гідромоніторного розмиву та у розробці математичної моделі, що описує процес свердловинного гідровидобутку.

Практична значимість. Створення математичної моделі, що дозволяє проводити розрахунок та вибір обладнання для проведення процесів свердловинного гідровидобутку.

Ключові слова: свердловинний гідровидобуток, моделювання, гідромонітор, очисний простір, робоча рідина

\section{ABSTRACT (IN RUSSIAN)}

Цель. Проанализировать процесс скважинной гидродобычи. Определить основные показатели гидромониторного размыва. Создать математическую модель, которая будет описывать процесс скважинной гидродобычи полезных ископаемых.

Методика. Произведен анализ процесса скважинной гидродобычи как объекта моделирования. Получены математические зависимости, описывающие этапы процесса размыва полезных ископаемых и поднятие их на поверхность.

Результаты. Определены основные задания скважинной гидродобычи и основные процессы, характеризующие ее. Определен алгоритм математического моделирования процесса скважинной гидродобычи. Рассчитаны основные показатели гидромониторного размыва. Получены математические зависимости, описывающие процесс скважинной гидродобычи полезных ископаемых.

Научная новизна. Научная новизна состоит в анализе процесса скважинной гидродобычи, определении основных показателей гидромониторного размыва и разработке математической модели, описывающей процесс скважинной гидродобычи.

Практическая значимость. Разработана математическая модель, позволяющая производить расчет и выбор оборудования для реализации процессов скважинной гидродобычи.

Ключевые слова: скважинная гидродобыча, моделирование, гидромонитор, очистное пространство, рабочая жидкость

\section{ARTICLE INFO}

Received: 15 February 2016

Accepted: 5 April 2016

Available online: 30 June 2016

\section{ABOUT AUTHORS}

Zinovii Malanchuk, Doctor of Technical Sciences, Professor of the Department of Development of Deposits and Mining, National University of Water Management and Nature Resources Use, 8 Studentska St, 26, 33000, Rivne, Ukraine. E-mail: malanchykzr@ukr.net

Yevhenii Malanchuk, Doctor of Technical Sciences, Associate Professor of the Department of Automation, Electrical Engineering and Computer-integrated Technologies, National University of Water Management and Nature Resources Use, 8 Studentska St, 26, 33000, Rivne, Ukraine. E-mail: malanchykEZ@mail.ru

Andrii Khrystiuk, Senior Lecturer of the Department of Automation, Electrical Engineering and Computer-integrated Technologies, National University of Water Management and Nature Resources Use, 3 Bukovinska St, 118, 33027, Rivne, Ukraine. E-mail: a.khrystyuk@gmail.com 